УДК $350 ; 35.077$

DOI

\author{
М.C. Міхровська \\ orcid.org/0000-0002-0949-6124 \\ кандидат юридичних наук, \\ асистент кафедри адміністративного права та процесу \\ Інституту права \\ Київського національного університету ілені Тараса Шевченка
}

\title{
ДЕЯКІ АСПЕКТИ МОДЕРНІЗАЦЇ̈ ДЕРЖАВНОГО УПРАВЛІННЯ В КОНТЕКСТІ ЦИФРОВИХ ТРАНСФОРМАЦІЙ
}

Загальновідомим є той факт, що в Україні протягом тривалого часу відбуваються фундаментальні цифрові трансформації, які мають на меті докорінну зміну системи державної влади та місцевого самоврядування в Україні. Зміни носять глобальний характер і суттєво впливають на всі сфери життя суспільства.

Очевидно, що на шляху до цифрової держави вже було зроблено немало, і Україна впевнено рухається в цьому напрямку. Проте варто наголосити також і на недоліках, які неодмінно супроводжують будьякий трансформаційний процес, гальмуючи його.

Природно, що оскільки цифровізація як явище зачіпає всі сфери життя суспільства, то приймається чимало нормативно-правових актів ыз різних питань щодо впровадження цифрових технологій. Проте однією з очевидних проблем цього процесу $€$ надмірна кількість нормативних актів в цій сфеpi, які не пов'язані між собою, при цьому немає єдиного визначеного нормативного акта, який би містив дефініції у сфері цифровізації. Крім того, чи не єдиними визначеннями в цій сфері сьогодні є електронне урядування та цифровізація. Так, останне визначено як насичення фізичного світу електронно-цифровими пристроями, засобами, системами та налагодження електронно-комунікаційного обміну між ними, що фактично уможливлює інтегральну взаємодію віртуального та фізичного, тобто створює кіберфізичний простір [1]. Зауважимо декілька моментів:

1. Визначення не має жодної прив'язки до процесів, що відбуваються в державі. Тобто за цими визначеннями, не можемо вважати таке явище, як «цифровізація», таким, що здійснюється всередині держави 3 метою покращення взаємодії між нею та громадянами.

2. Не вказується сфера впровадження цифровізації. Тобто з визначення ми не можемо зрозуміти, як саме та в який спосіб цифровізація може привести до змін.

3. Не вказано кінцеву мету, з якою впроваджується це явище, що є надзвичайно важливим, оскільки під час пандемії та інших явищ цифровізація держави перетворилася на нагальну необхідністью
4. Не вказано, яким чином це поняття співвідноситься зі спорідненими явищами - оцифровуванням, цифровою трансформацією, цифровим (електронним урядуванням) тощо.

5. Немає згадки про сервісну складову частину цього поняття, адже саме вона є основним аргументом щодо повсюдного провадження цифровізації.

6. Надане визначення міститься в концептуальному документі підзаконного характеру в Концепції розвитку цифрової економіки та суспільства України на 2018-2020 роки та затверджена розпорядженням Уряду України, тобто на рівні закону визначення відсутнє.

7. Вказана Концепція є єдиним документом, що надає визначення, $\mathrm{i}$, як очевидно 3 назви, вона стосується виключно сфери економічного розвитку, а не цифрових трансформацій держави загалом.

Щодо визначення електронного урядування, то вперше воно було надано в 2010 році в Концепції розвитку електронного урядування [2] і виглядало таким чином: «Електронне урядування - форма організації державного управління, яка сприяє підвищенню ефективності, відкритості та прозорості діяльності органів державної влади та органів місцевого самоврядування з використанням інформаційно-телекомунікаційних технологій для формування нового типу держави, орієнтованої на задоволення потреб громадян» Згодом, у 2017, воно було продубльовано у новій Концепції розвитку електронного урядування [3] без будь-яких змін. Це визначення, на нашу думку, містить важливі складові частини, такі як сервісна складова частина та ціль, яку переслідує держава, впроваджуючи таке явище. Проте основним його недоліком є відсилка до системи державного управління, формою організації якого воно (електронне урядування) нібито виступає. Насправді, цей аспект не можна вважати несуттєвим із декількох причин, а саме:

1. Словосполучення «державне управління» не вживається в Конституції України, Основний Закон оперує лише терміном «управління державними справами», що не є випадковістю. 
2. Термін «державне управління» має абсолютно конкретне «забарвлення», яке робить відсилку до радянського минулого нашої держави, за якої саме державне управління, на противагу західним концепціям розподілу влад, визначалося одним із «видів влади» замість сучасної виконавчої гілки влади [4], оскільки в науці адміністративного права радянського періоду категорія «державне управління» вважалася базовою і домінуючою. Зокрема, за радянських часів державне управління визначалося як один із чотирьох основних видів діяльності держави поряд із такими її видами, як здійснення: а) власне державної влади - це діяльність рад народних депутатів усіх рівнів; б) правосуддя; в) прокурорського нагляду. Натомість нині, із запровадженням в Україні конституційного принципу поділу державної влади, подібна класифікація видів державної діяльності втратила своє значення [5, с. 113]. Україна ж, обравши шлях незалежності і обравши демократизацію і гуманізацію стосунків між державою і суспільством своїм головним і беззастережним пріоритетом, назавжди відмовилася від цієї радянської концепції, що було підтверджено прийняттям Конституції;

3. Державне управління - це діяльність виконавчо-розпорядчого характеру, основним напрямком якої є виконання, тобто проведення в життя законів та підзаконних нормативно-правових актів [6, с. 17]; це цілеспрямований, організуючий i регулюючий вплив держави через систему її органів та посадових осіб на суспільні процеси, свідомість, поведінку і діяльність людей, що здійснюється в межах суб'єктивного фактора (суспільства) як управляючий вплив одних людей, організованих у владні структурі, на інших, головним чином зайнятих у сферах відтворення матеріальних, соціальних та духовних цінностей та продуктів [7, с. 38]; за своїм змістом державне управління базується на імперативних методах досягнення цілей, що йде врозріз із сучасною української державою, її концептуальними прагненнями.

4. Державне управління передбачає, окрім іншого, переважно наявність субординаційних відносин, із певним додаванням відносин координації, тоді як у сучасній демократичній державі, яка стоїть на порозі трансформаційних змін, невід'ємним атрибутом є саме відносини реординації - зв'язки відносно нового типу та характеру. Реординаційні відносини можна визначити як відносини у сфері соціального управління, за яких об'єкт управління наділений правом вимагати від суб'єкта управління належного виконання наданих йому функцій із метою реалізації, захисту або відновлення його прав, свобод та законних інтересів [8, с. 92]. Для демократичних країн реординація є постійним супутником не лише координації, але і субординації [9, с. 147]. I якщо для субординації характерна наявність владних повноважень у вищого рівня в системі управління відносно нижчого, то для реординаційних відносин характерні зв'язки зворотного впливу - нижчий рівень має право впливу на вищий. Найбільш поширений випадок - коли керований об'єкт повідомляє про свої наміри або подає клопотання, а керівний суб'єкт зобов'язаний на них у певний спосіб відреагувати. До того ж реординаційні зв'язки необов'язково є реакцією на той чи інший управлінський вплив, а можуть виникнути незалежно від них і мають не просто інформаційний, а управлінський характер [10, с. 228-230].

5. Державне управління має зовсім іншу мету, аніж сучасне публічне управління: «Під «публічною адміністрацією» розуміється система органів публічної влади, які здійснюють свої завдання у сфері функціонування держави виключно в інтересах суспільства" [11].

Тепер звернемося безпосередньо до терміна «цифрова трансформація». Коли ми ведемо мову про трансформацію якогось явища, відразу виникають асоціації про перехід від старого до нового, оновлення чогось, перетворення. Якщо звернутись безпосередньо до словника, то можна знайти визначення трансформації як зміни, перетворення виду, форми, істотних властивостей і т. ін. чого-небудь [12].

Щодо українського законодавства, то цифрова трансформація визначається як діяльність, що має на меті використання цифрових технологій для вирішення традиційних проблем інноваційними способами» [13]. Проаналізувавши цю дефініцію, можна зробити такі очевидні висновки:

1. Основою цифрових трансформацій є цифрові технології.

2. Цифрові трансформації - це шлях інновацій, тобто того, що не було раніше застосовано.

3. Поняття «цифрові трансформації» є універсальними, тобто може застосовуватись в будь-якій сфері, не маючи прив'язки до процесів управління всередині держави.

Якщо говорити про інший термін, що часто вживається - цифрові перетворення, то він є тотожним терміну «цифрове перетворення», оскільки є його перекладом з англійської.

Важливо зауважити, що сьогодні цифрова трансформація та її складові частини є найпершими пріоритетами нашої держави, про що зазначається в багатьох законодавчих актах концептуального характеру і не тільки. Так, Уряд визначив, що «пріоритетом діяльності Кабінету Міністрів України є забезпечення цифрової трансформації основних галузей та сфер суспільного життя, доступу громадян до якісних та зручних публічних послуг, розвитку інструментів електронної демократії та відкритих даних" [14]. 
Варто звернути увагу, що в документах міжнародних організацій цифрові трансформації часто ототожнюють з іншим явищем, що набирає надзвичайної популярності останнім часом - цифровим урядуванням, що приходить на заміну урядування електронного.

$\mathrm{y}$ царині науки поширене таке визначення, де цифрове врядування врядування - це сервісно-орієнтована організація функціонування системи публічного врядування на основі цифрових технологій [15]. Основне, на чому робиться акцент в цьому визначенні, - його сервісна орієнтованість, із чим важко не погодитись. Важливо підкреслити, однак, що ця «сервісна складова» неодмінно має супроводжувати громадян на всіх рівнях взаємодії з державою - від початку і до отримання результату.

Наприклад, міжнародні організації, такі як Організація Об'єднаних Націй, вказують, що необхідними для втілення концепції цифрового урядування та цифрової трансформації є такі кроки, як: бачення, лідерство, мислення; інституційна та нормативна база: розробка інтегрованої інституційної екосистеми за допомогою всеохоплюючої нормативної бази; організаційна структура та культура; інфраструктура інформаційно-комунікаційних технологій, доступність технологій тощо [16].

Отже, приходимо до висновку, що цифрова трансформація - це перехід до нового рівня взаємодії між державою та громадянином, де на перший план починають виходити не кількісні показники, а якісні, і де пріоритетом є не лише швидкість та доступність двостороннього їх спілкування, а саме дотримання прав, свобод та інтересів людини і громадянина та, звісно, результат, за яким громадянин і звернувся до відповідного органу.

У контексті проведеного аналізу стає очевидно, що як цифрова трансформація, так і електронне урядування, і цифрове урядування, а також інші явища у сфері цифровізації мають основну єдину мету - підвищити рівень взаєморозуміння між державою та громадянами, використовуючи при цьому сучасні цифрові технології.

Таким чином, можна прийти до висновку, що в державного управління як явища і у цифрової трансформації абсолютно протилежними є і мета, заради якої здійснюється цей процес, і засоби його досягнення, а також суб'єктний склад та характер зв'язків між цими суб'єктами, отже, важливим $\epsilon$ вилучення терміна «державне управління» 3 нормативно-правових актів всіх рівнів з питань, що стосуються цифрового розвитку та цифрових трансформацій; заміна такого терміна на більш демократичні аналоги - «публічна адміністрація» або ж «публічне управління», які сьогодні використовуються абсолютною більшістю демократичних країн, а також прийняття окремого закону, який би визначив такі поняття, як: цифрові трансформації (цифрові перетворення), цифрове урядування, електронне урядування, цифровізація (діджиталізація), електронна (цифрова) демократія тощо.

\section{Jimepamypa}

1. Концепція розвитку цифрової економіки та суспільства України на 2018-2020 роки. Розпорядження Кабінету Міністрів України. №67-p. 2018. URL: https://zakon.rada.gov.ua/laws/show/67-2018p\#Text.

2. Про схвалення Концепції розвитку електронного урядування в Україні. Розпорядження Кабінету Міністрів України. 2010. № 2250-р. URL: https://zakon.rada.gov.ua/laws/show/2250-2010p\#Text (втратив чинність).

3. Про схвалення Концепції розвитку електронного урядування в Україні. Розпорядження Кабінету Міністрів України. № 649-p. 2017. URL : https://zakon. rada.gov.ua/laws/show/649-2017-p\#Text.

4. Конституція (Основний Закон) України : прийнятя Верховною Радою Української РСР 20 квіт. 1978 p. URL : www. zakon1.rada.gov.ua (втратив чинність)

5. Авер'янов В. Ще раз про зміст і співвідношення понять «державне управління» і «виконавча влада»: полемічні нотатки. Право України : Респ. юрид. журнал. 05/2004. № 5. С. 113-116.

6. Нижник Н.Р. Деякі аспекти сучасної концепції державного управління в Україні. Вісник УАДУ. 1995. Вип. 4. С. 17-18.

7. Атаманчук Г.В. Теория государственного управления: Курс лекций. Юрид. Лит., 1997. 400 с.

8. Міхровська М. Роль реординаційних відносин у демократизації виконавчої влади. Вісник $\mathrm{Ku}$ ївського національного університету імені Тараса Шевченка. Юридичні науки. 2013. Вип. 2. С. 91-93. URL: http://nbuv.gov.ua/UJRN/VKNU_Yur_2013_2

9. Бурганова Л.А. Социология управления : учебник. Киев : Изд-во КГТУ, 2007. 246 с.

10. Курашвили Б.П. Очерк теории государственного управления. Наука. 1987. 294 с.

11. Білозерська Т.О. Реформування публічної адміністрації в Україні як крок до європейської інтеграціï. URL : www.nbuv.gov.ua/e-journals/FP/20072/07btodei.pdf.

12. Трансформація. Словник української мови. URL : http://sum.in.ua/s/transformacija.

13. Про забезпечення реалізації деяких питань цифрового розвитку (наказ Державного агентства з питань електронного урядування України). № 24. 2019. URL : https://zakon.rada.gov.ua/rada/show/v002488319\#Text.

14. Про затвердження плану дій із впровадження Ініціативи «Партнерство «Відкритий Уряд» у 2021-2022 роках (розпорядження Кабінету Міністрів України). № 149. 2021. URL : https://zakon.rada.gov. ua/laws/show/149-2021-p?find=1\&text=цифров+трансформац\#ш2 1 .

15. Куйбїда В.С., Карпенко О.В., Наместнік В.В. 2018. Цифрове врядування в Україні: базові дефініції понятійно-категоріального апарату. Вісник Наиіональної академії державного управління при Президентові України. Серія : Державне управління. № 1. С. 5-10. URL : http://nbuv.gov.ua/UJRN/vnaddy_2018_1_3.

16. United Nations E-government survey 2020. Digital Governmentin the Decade of Action for Sustainable 
Development.URL: https://publicadministration. un.org/egovkb/Portals/egovkb/Documents/un/2020. Survey / $2020 \% 20$ UN \% 20 E-Government $\% 20$ Survey\% 20(Full\% 20Report).pdf.

\section{Анотація}

Міхровська M. С. Деякі аспекти модернізації державного управління в контексті цифрових трансформацій. - Стаття.

Вже більше десяти років в Україні відбуваються важливі перетворення, які, вживаючи сучасну термінологію, можна визначити як цифрові трансформації. Загалом, трансформація - це перехід від застарілих засад, принципів до чогось нового та сучасного. Тоді як цифрова трансформація - явище нового характеру, це повна зміна алгоритму спілкування між державою та громадянином за допомогою новітніх цифрових технологій, які впроваджуються в усі сфери життя суспільства. Елементами цифрових трансформацій ми можемо визначити і цифровізацію, і оцифровування, електронне та цифрове урядування. Автор звертає увагу на сучасний стан закріплення цих явищ у законодавстві України та на недоліки наявних визначень.

Автором зауважено, що одним із небагатьох визначень, яке $є$ в законодавстві України в цій сфеpi, є визначення електронного урядування. Звернено особливу увагу на те, що ця дефініція надана через призму державного управління, яке не тільки є застарілим явищем, що дісталося нам у спадок від радянського минулого, а ще і не вживається в Основному Законі. Проаналізовано, що державне управління характеризується певними особливостями, такими як визначений суб'єктний склад та специфіка у зв'язках між суб'єктами.

У статті підкреслено, що цифрова трансформація та цифрове урядування для України є новими, майже не дослідженими явищами, тоді як у багатьох інших країнах ці поняття вже давно стали невід’ємною складовою частиною повсякденного життя. Міжнародні організації також часто вживають ці терміни як синонімічні та не проводять чіткого розмежування між ними.

Автором зроблено висновки, що через ряд об'єктивно зумовлених причин ні електронне урядування, ні цифрова трансформація та її складові частини не можуть визначатися через призму державного управління, відтак необхідним є прийняття окремого закону, який би закріпив необхідні визначення у цифровій сфері.
Ключові слова: цифрова трансформація, електронне урядування, державне управління, цифрова сфера.

\section{Summary}

Mikhrovska M.S. Some aspects of state administation modernization in the context of digital transformations. - Article.

For more than ten years, important transformations have been taking place in Ukraine, which, using modern terminology, can be defined as digital transformations. In general, transformation is a transition from outdated principles, to something new and modern. While the digital transformation is a phenomenon of a completely new nature. It is a complete change in the algorithm of communication between the state and the citizen with the help of the latest digital technologies, which are implemented in all spheres of society. The main elements of digital transformations, are digitization, digitalization, e-government, and digital governance. The author draws attention to the current state of consolidation of these phenomena in the legislation of Ukraine and the drawbacks of existing definitions.

The author notes that one of the few definitions in Ukrainian legislation in this area is the definition of e-government. Particular attention is paid to the fact that this definition is given through the prism of old state administration, which is not only an outdated phenomenon that we inherited from the Soviet past, but also not used in the Basic Law. It is analyzed that state administration is characterized by certain features, such as a certain subject composition and specifics in the relations between the subjects.

The article emphasizes that digital transformation and digital governance are new, almost unexplored phenomena for Ukraine, while in many other countries these concepts are an integral part of everyday life. International organizations also often use these terms as synonyms and do not make a clear distinction between them.

The author concludes that for several objective reasons, neither e-government nor digital transformation and its components can be determined through the prism of state administration. Therefore, it is necessary to adopt a separate law that would establish all the definitions in the digital sphere.

Key words: digital transformation, e-government, state administration, digital sphere. 